\title{
TNF inhibits malaria hepatic stages in vitro via synthesis of IL-6
}

\author{
Andreas Nussler, Sylviane Pied, Joseph Goma, Laurent Rénia, \\ François Miltgen', Georges E. Grau', and Dominique Mazier \\ INSERM U313, Groupe PitiéSalpêtrière, 911 Bd de l'Hôptal, 75013 Paris, France \\ 'Museum National d'Histoire Naturelle, 61, rue Buffon, 75006 Paris, France \\ 2WHO-IRTC, Dept of Pathology, University of Geneva, Switzerland
}

Key words: Cytokines, effector mechanism, hepatocytes, infection, liver, pre-erythrocytic stages, non-parenchymal cells

\begin{abstract}
We examined the capacity of murine recombinant tumor necrosls factor ( $\mathrm{rmTNF}$ ) to induce an inhibitory effect at the hepatic stage on malaria Induced by Plasmodium yoell sporozoltes. When Injected three tImes, $1.0 \mathrm{\mu g}$ of $\mathrm{rmTNF}$ was found to protect $78 \%$ of mice against a sporozolte challenge. In contrast, whatever the dose and the schedule of administration, no inhibition was observed when purified hepatocyte cultures were infected with $P$. yoelll. The addition of nonparenchymal hepatic cells to hepatocyte cultures restored the capaclty of TNF to modulate hepatic stage development, leading to up to 44\% Inhibitlon. Antibodies to interleukin 6 reversed the anti-parasite activity in the co-culture system.
\end{abstract}

\section{Introduction}

Tumor necrosis factor alpha/cachectin (TNF), initially described for its ability to Induce hemorrhagic necrosis in vivo $(1,2)$, is a cytokine with various activities, Including striking anti-viral (3), antibacterial (4) and anti-parasitic effects (5). In malaria, it has been shown that TNF administration in vivo protects mice challenged with parasitized erythrocytes of $P$. chabaudi (6) and reduces the development of hepatic forms of $P$. berghei (7). Although a previous report indicates that TNF reduced development of $P$. berghei in a Hep. G2 hepatoma cell line (7), preliminary data obtained in our laboratory using fresh hepatocytes did not confirm this effect. The aim of the present study was to understand the reasons for such discrepancies and to clarify the role of TNF, at the hepatic level, in sporozoite induced malaria.

\section{Methods}

Animals

Three-month-old BALB/C, C3H/HeJ, and C57B1/6 mice were purchased from Charles River Breeding Laboratories, Saint-Aubin les Elbeuf, France.

Cytokines and anti-cytokine antibodies

Murine recombinant TNF alpha (rmTNF) was a kind gift from Dr B. Allet, Glaxo IMB, Garouge, Switzerland. Rabbit anti-mouse TNF IgG was prepared as previously described (8). 6B4, a rat
IgG1 anti-mouse interleukin 6 (IL-6) (9) and murine recombinant IL-6 (rmlL-6) were a gift from Dr J. Van Snick, Ludwig Institute, Brussels, Belgium.

\section{Cytokine assays}

Supernatants from hepatocyte cultures were assayed for IL-6 in a bioassay using the 7TD1 cell line as described (10). Secretion of IFN-gamma in supernatants after stımulation with rmTNF was measured with an enzyme-linked immunoassay (ELISA) using a murine monoclonal antibody to IFN-gamma (11). Interleukin 1 (IL-1) was assayed by the standard thymocyte co-mitogen assay as previously described $(12,13)$.

\section{Parasites}

Sporozoites of the 17X strain of Plasmodium yoelii yoelii were obtained from infected salivary glands of Anopheles stephensi mosquitoes, 16 to 21 days after an infective mouse blood meal. After aseptic dissection, salivary glands were homogenized in a glass grinder and diluted in culture medium or sterile phosphate-buffered saline (PBS) (14).

\section{In vivo experiments}

Balb/c mice were divided into four groups. In the first group, each mouse received $1.0 \mu \mathrm{g}$ of rmTNF intravenously (i.v.). After $24 \mathrm{~h}$, each animal was injected with $3500 P$. yoelii sporozoites i.v. Each mouse in group 2 received $0.5 \mu \mathrm{g}$ rmTNF i.v. $24 \mathrm{~h}$ before, during, 
and $24 \mathrm{~h}$ after sporozoite inoculation. The third group was treated as the second group but the rmTNF dose was $1.0 \mu \mathrm{g}$. In the control group rmTNF was replaced by $0.2 \mathrm{ml}$ of PBS and the regimen was as for group 2 . Blood smears, taken daily from the third to the seventeenth day after sporozoite inoculation, were staıned with Giemsa and examined for erythrocytic stages of P. yoelii.

\section{Culture of hepatic stages of malaria parasites}

Monoculture of hepatocytes. Rodent hepatocyte monolayers (BALB/c, C3H/HeJ, C57BL/6) were isolated by collagenase perfusion of liver fragments as previously described (15). Briefly, 60000 cells were cultured in elght-chamber plastic Lab-Teck slides (Miles Lab. Inc., USA) in minimal essential medium supplemented with $10 \%$ fetal bovine serum and incubated with $5 \% \mathrm{CO}_{2}$ at $37^{\circ} \mathrm{C}$ for $24 \mathrm{~h}$ before use in experiments.

Co-culture of hepatocytes and non-parenchymal cells (NPC). NPC were obtained as already described (16). Briefly, livers from mice (BALB/C, C57BL/6) were perfused with HEPES buffer followed by pertusion with $0.05 \%$ collagenase (Collagenase $\mathrm{H}$, Boehringer Mannheim, Germany). Then the distended and blanched liver was teased and suspended in $30 \mathrm{ml}$ collagenase solution and maintaned for $45 \mathrm{~min}$ at $37^{\circ} \mathrm{C}$ under magnetic agitation. The suspension was then centrifuged at $300 \mathrm{~g}$ for 10 min, the supernatant discarded, and the pellet resuspended in $5 \mathrm{ml}$ HEPES. The liver cell suspension was overlaid with $7 \mathrm{ml}$ $30 \% \mathrm{w} / \mathrm{v}$ metrizamide (Nicomed, Oslo, Norway), dissolved in HEPES without $\mathrm{NaCl}$. The liver cell metrizamide gradient was centrifuged at $1400 \mathrm{~g}$ for $20 \mathrm{~min}$. NPC were collected from the top layer, washed twice in HEPES and resuspended in tissueculture medium. Sixty thousand viable NPC were added to primary hepatocyte cultures $3 \mathrm{~h}$ after the culture was set up (ratio $1: 1)$.

Treatment of monocultures and co-cultures. Both culture types were incubated with $0.5,1.0$ or $2.5 \mu \mathrm{g} / \mathrm{ml} \mathrm{rmTNF}$. Control cultures were maintained without rmTNF. Forty thousand $P$. yoelii sporozoites were added $24 \mathrm{~h}$ after rmTNF addition. Three and $24 \mathrm{~h}$ after sporozoite inoculation culture supernatants were taken for cytokine assays and replaced either with fresh medium or with medium containing rmTNF. Forty-eight hours after sporozoite inoculation, supernatants were taken again for cytokine assays and cultures were stopped and stained with Giemsa to find schizonts. In addition, other cultures of both types were incubated with $10 \mathrm{IU} / \mathrm{ml} \mathrm{rmlL}-6$ for $24 \mathrm{~h}$ before sporozoltes were inoculated; these cultures were stopped $48 \mathrm{~h}$ later.

Neutralization of IL- 6 by an anti-IL-6 mAb. Using the same protocol as described in the previous paragraph, anti-murine IL-6 $\mathrm{mAB}(1 / 100)$ was added to cultures either at the time of cytokine incubation or 30 minutes before sporozoite inoculation. The cultures were then maintained as described above.

\section{Results}

\section{In vivo experiments}

Injection of $1.0 \mu \mathrm{g} \mathrm{rmTNF}$ the day before, at the time of, and the day after inoculation of 3500 sporozoites prevented occurrence of parasitemia in $78 \%$ of the mice. This was a consistent finding.
Table 1. Effect of in vivo TNF administration on $P$. yoelii sporozoite infection in BALB/c mice

\begin{tabular}{lllll}
\hline $\begin{array}{l}\text { Treatment } \\
\text { rmTNF }(\mu g \text { /mouse) }\end{array}$ & & $\begin{array}{l}\text { Protection } \\
\text { (number of mice) }\end{array}$ & Delay \\
\hline$-24 \mathrm{~h}$ & $+3 \mathrm{~h}$ & $+24 \mathrm{~h}$ & & \\
\hline 0.5 & 0.5 & 0.5 & $0 / 5$ & 1 day \pm 0.8 \\
1 & - & - & $1 / 10$ & 4 days \pm 1.5 \\
1 & 1 & 1 & $16 / 20$ & 5 days \pm 10 \\
0 & 0 & 0 & $2 / 20$ & \\
\hline
\end{tabular}

aDelay represents the specific mean $\pm S E$ in the appearance of parasitemia in non-protected mice, compared to controls injected with PBS.

\section{Effect of TNF in the presence of NPC}

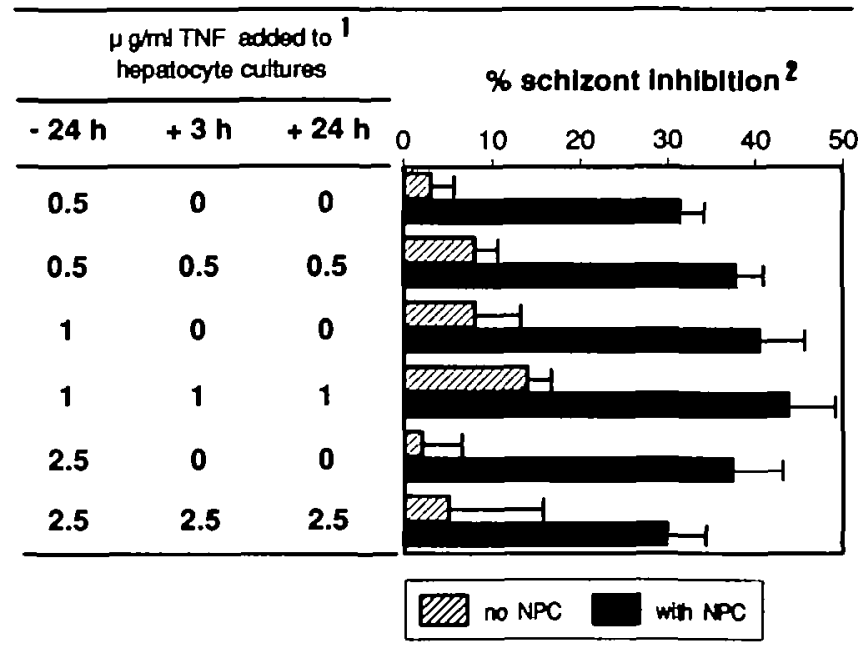

Flg. 1. Effect of TNF in the presence of NPC. ${ }^{1} \mathrm{rmTNF}$ was added at different times (indicated in hours) after sporozoite inoculation. 2Percentage inhibution was estimated by counting numbers of $48 \cdot \mathrm{h}$ schizonts in cultures with or without rmTNF. Results are expressed as means \pm SEM of six individual cultures. The controls were either hepatocytes without NPC (Schizont number: $65 \pm 3$ ) or hepatocyte with NPC (Sehizont number: $70 \pm 6$ ).

mice being aparasitaemic 17 days after infection. In the remanning $20 \%$ of treated but non-protected mice, the rise in parasitemia was delayed by a mean of 5 days compared to PBS treated mice. A single injection of rmTNF $(1.0 \mu \mathrm{g} /$ mouse $) 24 \mathrm{~h}$ before sporozoite inoculation was much less protective (Table 1). A lower dose of rmTNF ( $0.5 \mu \mathrm{g} /$ mouse), even when administered three times (the day before, on the day of, and $24 \mathrm{~h}$ after sporozoite inoculation) had no protective effect.

\section{In vitro experiments}

Effects of TNF on parasite devedopment in vitro. Using BALB/C hepatocyte monocultures (Fig. 1), no significant parasite inhibition could be observed when cultures were incubated with 0.5 $\mu \mathrm{g} / \mathrm{ml} \mathrm{rmTNF} 24 \mathrm{~h}$ before sporozoite inoculation. This effect was not improved by repeating the TNF administration ( $24 \mathrm{~h}$ before, during, and $24 \mathrm{~h}$ after infection), nor by increasing the dose to $2.5 \mu \mathrm{g} / \mathrm{ml}$. Similar results were obtained with primary cultures from 


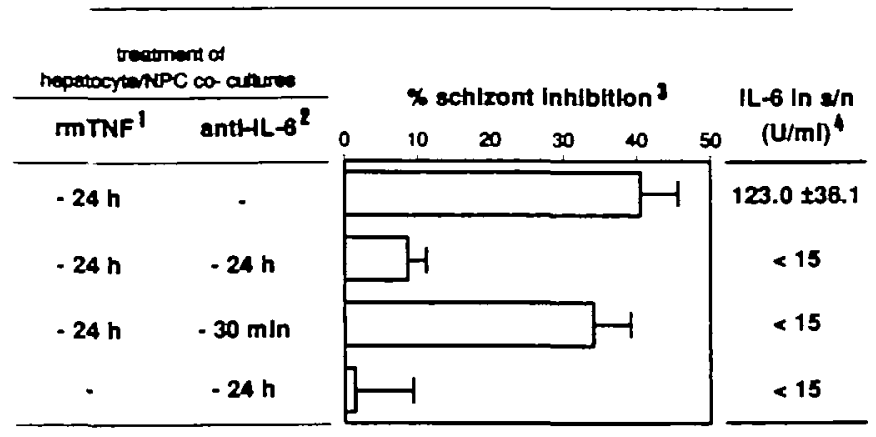

Fig. 2. IL-6 levels in culture supernatants. $11.0 \mu \mathrm{g} / \mathrm{ml}$, final concentration 21:100, final dilution. ${ }^{3}$ Results of six individual cultures, expressed as means \pm SEM, compared to infected hepatocyte cultures without TNF. The schizont number in untreated control cultures was $86 \pm 7 .{ }^{4}$ Assayed $3 \mathrm{~h}$ after sporozorte inoculation.

Table 2. Effects of in vitro IL-6 incubation on the pre-erythrocytic parasite development of $P$. yoelii in Balb/c hepatocyte cultures, in the presence and absence of non-parenchymal cells (NPC)

\begin{tabular}{|c|c|c|c|}
\hline \multicolumn{2}{|c|}{ Treatment } & \multicolumn{2}{|c|}{96 Inhibutione } \\
\hline$r m \mid L-6^{a}$ & antı-1L-6b & no NPC & with NPC \\
\hline $\begin{array}{l}-24 h \\
-24 h \\
-24 h \\
- \\
-\end{array}$ & $\begin{array}{l}- \\
-24 \mathrm{~h} \\
-30 \mathrm{~min} \\
-24 \mathrm{~h} \\
-30 \mathrm{~min}\end{array}$ & $\begin{array}{r}422 \pm 33 \\
5.2 \pm 45 \\
37.6 \pm 6.4 \\
4.0 \pm 38 \\
3.2 \pm 4.0\end{array}$ & $\begin{array}{r}86.5 \pm 7.0 \\
7.3 \pm 4.0 \\
79.0 \pm 7.5 \\
2.5 \pm 6.5 \\
6.8 \pm 20\end{array}$ \\
\hline
\end{tabular}

$\mathbf{a}_{10} \mathrm{IU} / \mathrm{ml}$, final concentration.

b1/100, final dilution

cPercentage inhibition of schizont devetopment of six individual cultures; expressed as means $\pm S E M$, compared to infected non-treated hepatocyte cultures. The schizont number in control cultures was without NPC $75 \pm 4$, and with NPC $69 \pm 5$.

C3H/HeJ and C57/BL6 mice (data not shown). The addition of NPC to hepatocyte cultures (ratio 1:1), in the presence of 0.5 $\mu \mathrm{g}$ TNF resulted in 31\% schizont inhibition (Fig. 1). The degree of inhibition was not improved by repeating the addition of TNF ( $24 \mathrm{~h}$ before, during, and $24 \mathrm{~h}$ after inoculation) nor by increasing the dose to $2.5 \mu \mathrm{g} / \mathrm{ml}$. Identical results were obtained using cocultures from $\mathrm{C} 57 / \mathrm{BL} 6$ and $\mathrm{C} 3 \mathrm{H} / \mathrm{HeJ}$ mice (data not shown). However, incubation of lower doses of rmTNF were less effective than those shown in Fig. 1 (data not shown).

Effects of TNF-induced IL-6 secretion and its neutralization in culture supernatants. Purified murne hepatocytes were cultured alone or in the presence of NPC (co-culture). Both culture types were incubated with $1.0 \mu \mathrm{g} / \mathrm{ml} \mathrm{rmTNF} 24 \mathrm{~h}$ before sporozoite inoculation and IL-6 levels were measured in supernatants (Fig. 2). It was found that IL-6 levels were high in co-cultures $3 \mathrm{~h}$ after sporozoite inoculation (mean: $123 \mathrm{U} / \mathrm{ml}$, Fig. 2) and rose to a mean of $490 \mathrm{U} / \mathrm{ml}$ after $48 \mathrm{~h}$, whereas IL-6 was not detectable in monocultures. Addition of anti-IL-6 mAb to co-cultures at the time of rmTNF incubation virtually abolished the inhibitory effect induced by TNF. In contrast, the addition of anti-IL- 6 mAb 30 min before sporozoite inoculation did not modify the rmTNF effects $(36 \pm 5.6 \%$ inhibition; Fig. 2), despite the fact that IL-6 remained undetectable after $3 \mathrm{~h}$. Neither IFN- $\gamma$ nor IL-1 could be detected in primary or in co-culture supernatants at 3,24 and $48 \mathrm{~h}$ after sporozoite inoculation, incubated or not with rmTNF.

Effects of murine recombinant $I L-6$ and its neutralization by an anti-IL-6 $m A B$. Incubation of rmIL-6 inhibited parasite development up to $42 \pm 3.3 \%$ in primary cultures, while $86 \pm 7.0 \%$ inhibitIon was reached in co-cultures. With an anti-murine IL $-6 \mathrm{mAb}$ $(1 / 100)$ nearly $90 \%$ of the $\mathrm{rmIL}-6(10 \mathrm{IU} / \mathrm{ml})$ induced inhibition could be neutralized in both primary and co-cultures (Table 2).

\section{Discussion}

The in vitro studies presented here were performed in order to define the site and mode of action of TNF. It is shown that when primary hepatocyte cultures are used instead of tumor cell lines, TNF fails to induce a protective effect, whatever the dose and the schedule of administration and whatever the strain of mice. These results are in contrast to a recent study, where TNF was found to inhibit development of $P$. berghei in a Hep. G2 cell line (7). We have shown that acute-phase proteins (APPs) secreted after cytokine stımulation $(17-19)$ Inhibit parasite development in vitro and in vivo $(20-22)$. Therefore, the fact that TNF induces different APPs in tumor cell lines and in normal rat hepatocytes $(23,24)$ might explain the differences observed in these two experimental models. Since a TNF dose of $1 \mu \mathrm{g} /$ mouse clearly protects in vivo without inducing necrosis (25) but has no effect on hepatocytes in vitro, we questioned whether an in vitro model containing only hepatocytes was valid. We found in these experiments that the addition of NPC to hepatocytes restored the capacity of TNF to modulate parasite hepatic stage development (Fig. 1). In our co-culture assay, NPC essentially consist of pit cells (large granular lymphocytes), Kupffer cells, T-cells, natural killer cells, endothelial cells from sinusoids, epithelial cells, fibroblasts and lto cells. Some of these cells are known to produce one or several of the following cytokines: IFN- $\gamma, I L-1$, and IL-6 $(26-28)$, all of which are known to interfere with the hepatic stages $(29-32)$. We recently demonstrated that IL-6 induces various effector mechanisms including oxygen radicals (31) and nitrites (32).

In these co-cultures, markedly elevated IL-6 concentrations were found upon addition of TNF, whereas IL- 1 and IFN- $\gamma$ remained undetectable. To confirm that IL-6 was directly involved in the TNF-induced parasite inhibition, anti-IL-6 mAb was added to mono- and co-cultures of hepatocytes. Anti-IL-6 $\mathrm{mAb}$ dramatically decreased the TNF-induced inhibition when added $24 \mathrm{~h}$ before sporozoite inoculation. The preservation of TNF effects when addition of anti- IL $-6 \mathrm{mAb}$ was delayed until $30 \mathrm{~min}$ before sporozoite inoculation showed that the release of IL-6 and the subsequent modification inside the hepatocytes takes place in the very early phase of culture after TNF introduction. This is consistent with the observation of high IL-6 concentrations in 24 and $48 \mathrm{~h}$ culture supernatants (data not shown), even when initial IL- 6 production had been neutralized by the addition of anti-IL- 6 mAb. The specific inhibitory effect of IL-6 on pre-erythrocytic stages of parasite development was furthermore demonstrated by incubating hepatocyte cultures directly with rmIL-6 (Table 2). These results strongly suggest that IL-6 is a crucial mediator of the observed TNF effect. The higher inhibitory effect of IL-6 on 
the parasite development observed in the presence of NPC suggests a stimulation in NPC of additional factors such as yet to be identified cytokines or substances that act synergistically with IL-6 (33).

TNF has also been demonstrated to be involved in L-argininedependent cytotoxic effector mechanisms in macrophages (34) which can have parasiticidal effects $(32,35,36)$.

In malaria the production of various cytokines, and particularly of TNF, is increased during the blood stage $(37,38)$, and these cytokines might modulate infection by liver stages. Furthermore, it has been shown that cytotoxic T cells are involved in the protection induced by immunization with irradiated sporozoites $(39,40)$. We recently demonstrated that immunization with peptide corresponding to the non-repetitive part of the circumsporozoite of $P$. yoelii, induced CD4 + and CD8 + T cells effective in the destruction of cultured hepatic schızonts (41; Rénia et al., in preparation). Moreover, these $\mathrm{T}$ cells are known to produce cytokines which include TNF and IL-6 (42). Taken together, these data further illustrate the interdependence of different stages of development in malaria parasites.

\section{Acknowledgements}

This research was supported in part by the United Nations Development Program-World Bank-Heatth Organisatıon Special Program on tranning and research in Tropical Diseases, the Commission des Communautes Europennes, the Fondations Raoul Follereau and the Consen Scientifique Pitie-Salpetriere. We wsh to thank Mr Bertho for assistance with IL-1 assays, Dr Draper and Miss N. Uwechue for reviewing the manuscript, and Prof. G Target for critical discussion. Furthermore we would like to thank Dr van Snick for providing the recombinant murine IL-6 and the monoclonal antibody 6B4.

\section{Abbrevlations}

APP

IFN- $\gamma$

IL-1

IL-6

mAb

NPC

rmTNF

acute-phase protein

interferon gamma

interleukn 1

interleukin 6

monoctonal antibody

non-parenchymal cell

murine recombinant TNF

\section{References}

1 Carswell, E. A., Old, L. J., Kassel, R. L., Green, S., Fiore, N., and Williamson, B. 1975. An endotoxin-induced serum factor that causes necrosis of tumors. Proc. Natl Acad. Sci. USA 720:3666

2 Tracey, K. J, Vassara, H., and Ceramı, A. 1989. Cachectin/tumor necrosis factor. Lancet 1:1122.

3 Ito, M. and O'Malley, J. A. 1987. Antiviral effects of recombinant human tumor necrosis factor. Lymphokine Res. 6:309.

4 Havell, E. A. 1989 . Evidence that tumor necrosis factor has an important role in antibacterial resistance. J. Immunol. 143.2894.

5 Titus, R. G., Sherry, B., and Cerami, A. 1989. Tumor necrosis factor plays a protective role in expenmental murine cutaneous leishmaniasis. J. Exp. Med. 170:2097.

6 Clark, I. A., Hunt, N. H., Butcher, G. A., and Cowden, W. B. 1987. Inhibition of munne malaria (Plasmodium chabaud) in vivo by recombinant interferon gamma or tumor necrosis factor, and its enhancement by butylated hydroxyanisole. J. Immunol. 139:3493.

7 Schofield, L., Nussenzweig, R. S., and Nussenzweig, V. 1988. CD8+ T-cells and garnma-interferon required for immunity to sporozoite challenge. Report of the tenth meeting of the scientific working group on the immunology of Malaria. p. 17.

$8 \mathrm{Grau}, \mathrm{G}$. E. and Gretener, D. 1987. Prevention of murine cerebral malaria by low-dose cyclosporin A. Immunology 61.521

9 Vink, A., Coulie, P., Wauters, P., Nordan, R P, and Van Snıck, J. 1988. B cell growth and differentiation activity of interleukin-HP1 and related murine plasmacytoma growth factor. Synergy with interleukin 1. Eur. J. Immunot. 18:607.

10 Van Snick, J., Cayphas, S., Vink, A., Uyttenhove, C., Coulie, P. G. Rubira, M., and Simpson, R. J. 1986. Purification and $\mathrm{NH}_{2}$-terminal amino acid sequence of a T-cell derived lymphokine with growth factor activity for B-cell hybridomas. Proc. Natl Acad. Sci. USA 83:9679.

11 Stade, S. J. and Langhorne, J 1989. Production of interferon gamma durng infection of mice with Plasmodium chabaudi chabaudi. Immunobiology 179.353 .

12 Mizel, S. B., Oppenheimer, J. J., and Rosenstreich, D. L. 1978 Characterisation of lymphocyte-activatıng factor (LAF) produced by the macrophage cell line P388D. I. Enhancement of LAF production by activated T lymphocytes $J$ Immund $120 \cdot 1487$.

13 Koopman, W. J., Farrar, J. J., and Fuller-Bonar, J 1978. Evidence for identification of LAF as the adherent cell-derived medlator responsible for enhanced antibody synthesis by nude mouse spleen cells. Cell Immunot. 35.92.

14 Mazier, D. , Landau, I., Mitgen,F , Druilhe, P., Lambiotte, M., Baccam, D., and Gentlini, M. 1982. Infestation in vitro d'hépatocytes de Thamnomys adulte par des sporozoites de Plasmodium yoelii: schizogonie et liberation de merozoites infestants. C. R. Acad. ScI. Paris 294:963.

15 Mazier, D. Mellouk, S., Beaudoin, R. L., Texier, B., Drullhe, P., Hockmeyer, W., Trosper, P, Paul, C, Charoenvit, Y., Young, J., Miltgen, F., Chedid, L., Chigot, J. P., Galley, B , Brandicourt, O, and Gentilın, M. 1986. Effect of antibodies to recombınant and synthetic peptides on Plasmodium falciparum sporozoites in vitro Science 231:156.

16 Kirn, A., Steffan, A. M., Bıngen, A., Cinqualbre, J., and Gendrault, J. L. 1980 . Isolement et culture de cellules de Kupffer humaines. $C$. R. Acad. Sci. Paris 291:249.

17 Ramadori, G., Sipe, J. D., Dinarello, G. A., Orzet, S. B. B., and Colten, H. R. 1985 Pretranstational modulation of acute phase hepatic protein synthesis by murine recombinant interleukin 1 (IL-1) and purfied IL-1. J. Exp Med. 162.930.

18 Mortensen, R F., Shapiro, J., Lin, B. F., Douches, S , and Neta, R. 1988 Interaction of recombinant IL-1 and recombinant tumor necrosis factor in the induction of mouse acute phase proteins. J. Immunol. $140: 2260$.

19 Jablons, D. M., Mule, J. J., Mclntosh, J. K, Sehgal, P. B., May, L. T., Huang, C. M., Rosenberg, S. A., and Lotze, M. 1989. IL-6/IFN beta- 2 as a crculating hormone. Induction by cytokine administration in humans. $J$. Immunol 142:1542.

20 Mazier, D. Miltgen, F., Nudelman, S., Nussler, A., Rénia, L., Pied, S., Goma, J., and Gentulın, M. 1988. Pre-erythocytic stages of plasmodia. Role of specific and non-specific factors. Biol. Cell 64:165.

21 Pied, S., Nusster, A , Pontet, M., Miltgen, F., Matle, H., Lambert, P. H., and Mazier, D. 1989. C-reactive protein protects against preerythrocytic stages of malaria Infect Immun. 57.278.

22 Nussler, A., Pied, S., Pontet, M., Miltgen, F., Rénia, L., Gentilini, M., and Mazier, D. 0000. Inflammatory status and preerythocytic stages of malaria. Role of the C-reactive protein. Exp. Parasitol. 0000:000.

23 Andus, T., Heinnich, P. C., Bauer, J., Tran-Thi, T., Decker, K., Mảnned, D., and Northoff, H. 1987. Discrimination of hepatocyte-stimulating activity from human recombinant tumor necrosis factor alpha. Eur J. Immunol. 17:1193

24 Perlmutter, D. H., Dinarello, C A, Punset, P. I., and Colten, H. R. 1986. Cachectintumor necrosis factor regulates hepatic acurte-phase gene expression. J. Clin. Invest. 78:1378.

25 Piguet, P. F., Grau, G. E., and Vasselli, P. 1990. Subcutaneous pertusion of tumor necrosis factor induced local proliferation of fibroblasts, capillaries, and epidermal celts, or massive tissue necrosis. Am. J. Pathol. 136:103.

26 Lotze, M., Jink, F., Kabouridis, P., Tsoukas, C, Hirano, T., Kishimoto, T., and Carson, D. A. 1988. B cell stimulating factor 2 /interleukin 6 is a costimulant for human thymocytes and T lymphocytes. J. Exp. Med. 167:1253.

$27 \mathrm{Katz}, Y$ and Strunk, R. C. 1989. Similarities and differences in stimutation of expression of atternative pathway of complement and IFNbeta2/IL-6 genes in human fibroblasts. J. Immunot. 142:3862. 
28 Kohase, M., Hendriksen-DeStefano, D., May, L., Vicek, J., and Sehgal, P. B. 1986. Induction of beta-2-interferon by tumor necrosis factor: a homeostatic mechanism in the controt of cell proliferation. Cell $45 \cdot 659$.

29 Mellouk, S., Maheshwan, R. K., Rhodes-Feuillette, A., Beaudoın, R. L., Berbiguier, N., Matile, H., Mittgen, F., Landau, I., Pied, S., Chigot, J. P., Friedman, R. M , and Mazier, D. 1987. Inhibitory activity of interferons and interleukin 1 on the devetopment of Plasmodium talciparum in human hepatocyte cultures. J. Immund. 139:4192.

30 Ferreira, A., Schofield, L., Enea, V., Schellekens, H, Van Der Meade, P. Collins, W E., Nussenzweig. R. S., and Nussenzwerg, V. 1986. Inhibition of development of exoerythrocytic forms of malaria parasites by gamma interferon. Science 232:881.

31 Pied, S., Rénia, L., Nusster, A., Miltgen, F., and Mazier, D. 1990. Inhibitory activity of IL-6 on malaria hepatic stages. Parasti Immunol. 000:000.

32 Nusster, A., Drapier, J. C., Rénia, L., Pied, S., Miltgen, F., Gentilini, M., and Mazier, D 1990. L-Argınıne-dependent destruction of intrahepatic malaria parastes in response to tumor necrosis factor and/or interleukin 6 stimulation.

33 Schindles, R., Mancilla, J , Endres, S , Ghorbani, R., Clark, S. C , and Dinarello, C A 1990. Correlation and interactions in the production of interleukın-6 (IL-6), IL-1, tumor necrosis factor (TNF) in human blood mononuclear cells. IL-6 suppress IL-1 and TNT. Blood 75.40.

34 Drapier, J. C. Wietzerbin, J., and Hibbs, J. B. 1988 Interferon gamma and tumor necrosis factor induce the L-arginine-dependent cytotoxic effector mechanism in murine macrophages. Eur. $J$ Immunot. 18.1587.

35 Green, S. J., Monte, M. S., Hibbs, J. B., Jr , and Nacy, C. A. 1990.
Activated macrophages destroy intracellular Leishmania major amastıgotes by the L-arginıne-dependent killing mechanism. $J$. Immunat. 144:278

36 Adams, L. B., Hibbs, J. B., Jr., Taintor, R. R., and Krahenbuhl, J. L. 1990 . Microbiostatic effect of murine-activated macrophages for Toxopłasma gondii. Role for synthesis of inorganic nitrogen oxides from L-arginine. J. Immund. 144.2725.

37 Bate, C. A. W., Taverne, J., and Playłair, J. H. L. 1989 . Soluble malarial antigens are toxic and induce the production of tumor necrosis factor in vivo. Immunology 66:600.

38 Grau, G. E., Fajardo, L. F., Piguet, P. F., Allet, B., Lambert, P. H., and Vassali, P. 1987. Tumor necrosis factor (cachetin) as an essential mediator in murine cerebral malana. Science 237:1210

39 Schofield, L., Villaquiran, J., Ferrerra, A., Schellekens, H., Nussenzweig, R., and Nussenzweig, V. 1987. Gamma-interteron, $\mathrm{CDB}^{+} \mathrm{T}$ cells and antibodies required for immunity to malaria sporozoites. Nature 330.664 .

40 Weiss, W. R., Sedegah, M., Beaudon, R L , Miller, L. H., and Good, M. F. 1988. CD8+ T cells (cytotoxic/suppressors) are required for protection in mice immunized with malaria sporozotes. Proc. Natt Acad. ScI. USA 85:573

41 Mazier, D., Rénia, L., Nussler, A., Pied, S., Marussig, M., Goma, J, Grillot, D . Miltgen, F., Drapier, J. C , Corradin, G., del Giudice, and Grau, G. E. 1990 Hepatic phase of malana is the target of cellular mechanisms induced by previous and subsequent stages. A crucial role for IIver nonparenchymal cells. Immunot Lett. 25:65.

42 Mosmann, T. R. and Coffman, R. L. 1989. Heterogeneity of cytokine secretion pattern and functions of helper $T$ cells. Adv, Immunol 46:111. 